\title{
Yaratıcı Drama Destekli Yaratıcı Okuma Programı
}

\author{
Nilay Yılmaz * \\ İstanbul Bilgi Üniversitesi
}

\begin{abstract}
Özet
Türkiye Eğitim Gönüllüleri Vakfi'nın (TEGV) 34 ilde (11 Ĕ̆itim Parkı ve 55 Öğrenim Birimi’nde) uygulanmakta olan "Okuyorum Oynuyorum" isimli yaratıc okuma etkinliğine 2007-2008 güz ve bahar döneminde katılan, 9-13 yaş aralı̆̆ındaki çocuklar içinden rasgele seçilen 258 çocuk (121 kız ve 137 erkek) bu çalışmanın örneklem grubunu oluşturmaktadır.Kullanılan ölçüm aracı, Okuyorum Oynuyorum etkinliklerinin hedeflerine ve içeriğine uygun olarak, TEGV eğitim departmanı ve araştırmacı (programın danışmanı ve içerik sorumlusu) tarafindan çocukların okuma tutum ve davranışlarındaki değişimi belirlemek için hazırlanmıştır. Okuma Tutum Ölçeği'nin güvenirliği Cronbach alfa iç tutarlılık katsayısı ( $\alpha$ ) kullanılarak belirlenmiştir. Buna göre ölçeğin $\alpha$ değeri 79 olarak bulunmuştur. Okuma tutum ölçeği, etkinlik dönemi başında ve sonunda çocuklara uygulanmış ve yaratıcı okuma programının katılımcı çocuklar üzerindeki etkisi araştırılmıştır. Okuma tutum ve davranışları ile ilgili, çocuklar 30 ölçek maddesine "I'den (Kesinlikle Katılmıyorum), 4'e (Kesinlikle Katılıyorum)" kadar derecelendirilmiş bir ölçekte kendilerine uygun olan seçeneği işaretleyerek cevaplandırmışlardır. Okuma tutum anketi, "Yaratıcı Okuma", "Hoşlanma", "Kaygl" ve "Yeterlilik" olmak üzere dört alt boyuttan oluşmaktadır.Uygulamalar, her hafta 1,5 saatlik oturumlar biçimde, 8 hafta sürmüştür. Ön-test ilk oturumun başlangıcında, son-test ise sekizinci oturumun bitiminde verilmiştir. Gruplar, her hafta başka bir metin (öykü, şiirler ya da resim) üzerinde çalışmıştır. Her oturum, çocukları, o oturumda ele alınacak yapittaki konulara zihinsel ve bedensel olarak isindıracak isinma oyunlarlyla başlamış, ardından okuma-anlama becerilerini geliştirecek, öyküde anlatılanları düşündürecek ve sorgulatacak soruların yanı sıra oyunlarla ve doğaçlama, dramatizasyon, rol oynama, ritim, öyküşiir-şarkı yazma, donuk imge, iç ses, film kareleri, bilinç koridoru, rol içinde yazma, telefon görüşmesi, televizyon programı, pandomim, geriye dönüş vb yaratıcı drama teknikleri ile desteklenen çalışmalarla ile devam etmiştir. Araştırmanın sonuçlarl, sekiz hafta (12 saat) süren yaratıcı okuma uygulamaları sonucunda çocukların okuma tutumlarının olumlu yönde değişmeye başladığını göstermiştir. Bir başka deyişle, yaratıcı okuma uygulamaları sonrasında çocuklar kitaplardan ve okuma-anlama etkinliklerinden daha fazla hoşlanma eğilimi göstermişler, okuma süreci ile ilgili kaygllarl azalmış ve okuma-anlama konusunda kendilerini daha yeterli hissetmeye başlamışlardır. Çok yönlü düşünmeyi ögrretmek, düş gücünü geliştirmek ve okuma kültürü oluşturmak çok daha uzun soluklu çalışmalar gerektirmektedir. Ancak, yaratıcı okuma çalışmalarının, gerek Türkçe/Edebiyat ögretim programlarındaki geleneksel yaklaşımı değiştirme, gerekse eğitim anlayışındaki eksiklikleri giderme ve çocuklarda okuma heyecanı oluşturma yolundaki önemli adımlardan biri olduğu söylenebilir.
\end{abstract}

Anahtar sözcükler: Drama, yaratıcı okuma, okuma kültürü, okuma tutumu

· İstanbul Bilgi Üniversitesi, Fen Edebiyat Fakültesi, Türk Dili Birimi Öğretim Görevlisi 


\begin{abstract}
This study was conducted to find out the effect of creative drama based reading programme on the development of reading attitudes. The sampling of the study consisted of 258 children between the ages 9-13 attending to the reading programme called Okuyorum Oynuyorum (I'm Reading and Playing) at TEGV (The Organization of Volunteers of Education). "The Questionnaire Form of the Reading Attitudes" was used to collect data. It was developed by the researcher and a field expert at TEGV. The reliability coefficient was found as .79 by using Cronbach Alpha realibility coefficient. The questionnaire form consisted of four parts which are 'creative reading', 'liking', 'anxiety' and 'proficiency', including 30 items in total. Children responded the questions in the form by indicating 4 level styles "Strongly Agree", "Agree", "Disagree" and "Strongly Disagree". The scoring was sorted out starting from "Strongly Disagree" varying from 1 to 4 . The highest score a child gets in the form is 120 while the lowest one is 30. "The Questionnaire Form of the Reading Attitudes" was applied to the children at the very beginning of the programme as a pretest and at the end of programme as a post-test. For a duration of 8 weeks (12 hours), 8 reading materials in total (one for each week) including short stories, poems and pictures supported by creative tasks were applied. In the warm-up stages of each session children were expected to play the games which were related to the theme of the story. Then came storytelling, comprehension tasks expanded by creative works like drawing, creative writing etc. and drama techniques like improvisation, conscience alley, group sculpture, inner voice, interviews, letters, narration, private property, still photographs etc. Children were expected to express their thoughts and feelings using a variety of creative tasks. To purpose of this study was to create positive attitudes, thoughts and emotions for children's books and to arouse curiosity towards reading process in children. Among creative tasks the creative drama played a significant role in developing the positive attitudes towards reading. Depending on the results of study, children who took drama-based creative reading programme liked the reading process; their anxiety levels about reading were decreased and they felt proficient in reading comprehension.In conclusion, drama based reading programme is an invaluable tool for educators to help building the culture of reading for children because it supports every aspect of literacy development. And implementing a creative reading programme can be a good approach to promote children's interest in literacy because creative comprehension tasks encourage the affective aspects of reading in a valuable social context.
\end{abstract}

Keywords: Drama, creative reading, culture of reading, reading attitude 


\section{Giriş}

Türkçe öğretiminin temel işlevinin öğrencilerin bilişsel, duyuşsal ve devinimsel gelişimlerine katkıda bulunmak, dil bilinci ve duyarlılığı oluşturmak, dilsel becerileri geliştirmek ve okuma kültürü edinmiş bireyler yetiştirmek olduğu bilinir. Türkçe öğretim programının özel amaçlarına ulaşabilmek için bazı temel ilkeler bulunmaktadır. Bu ilkeleri Demirel (2004, s.18) şöyle sıralar: Dört temel dil becerisinin birlikte öğretilmesi; Anadil öğretiminin doğal bir ortamda yapılmas1; Türkçe öğretiminde bütün derslerden yararlanılması; Anadil kurallarını öğretirken tümevarım yaklaşımının izlenmesi; Temel dil becerileri ile öğretim etkinlikleri arasında sıkı bir ilişkinin kurulması; Konuların seçiminde tematik bir yaklaşım izlenmesi ve Dil becerileri geliştirmede çoklu ortamın sağlanması. Bu temel ilkelere ek olarak öğrencilere öğrendiklerini kullanma olanağ sağlayacak ortamların yaratılması, verilen bilgilerin günlük yaşama aktarılması, dersin planlanmasında bireysel farklılıkların dikkate alınarak öğretme etkinliklerine çeşitlilik getirilmesi gibi daha birçok yan ilke eklenebilir.

Ancak bu temel ve yan ilkelerden yola çıkılarak hazırlanan uygulamalarda geleneksel öğretim anlayışının yaygın olması, Türkçe öğretiminin bir bilgi dersi olarak kabul görmesi, genellikle öğretici (didaktik) metinler aracılığıyla metinden kopuk soyut dil alıştırmalarının yapılması, düşünsel gelişim ve duyarlılık kazandırma etkinliklerine yeterince yer verilmemesi sıklıkla rastlanılan durumlardır. Her ne kadar yeni öğretim programında bilgiden çok beceriye önem verilerek bilgiye işlevsellik kazandırılmaya çalışılmış, dersleri çekici hale getirmek için oyunla eğitim, oyun biçiminde öğretim ilkesi gözetilmiş, eğitimcilere derste yapabilecekleri etkinlikler ve farklı öğretim yöntemleri önerilmiş olsa da hâlâ Türkçe öğretim ortamının değişik uyaranlarla zenginleştirilmesi ve programın aksayan ya da işlemeyen bölümlerine yönelik çalışmalar yapılması gerekmektedir. Ayrıca Türkçe öğretim programının sadece ders saatlerinde değil, ders dışı zamanlarda da öğrencileri yazınsal metinleri okumaya yönlendirici ve heveslendirici bir yaklaşıma sahip olmasının gerekliliği gözden kaçırılmaması gereken diğer bir konudur.

$\mathrm{Ne}$ var ki kağıt üzerinde mükemmel görünen öğretim programlarının uygulama alanlarında beklenen başarıyı sağlayamadığı da görülmektedir. PIRLS ve PISA araştırmaları Türk eğitim sisteminin son zamanlardaki durumuna 1şık tutan çalışmalardan sadece ikisidir. PIRLS, Uluslararası Eğitim Başarılarını Belirleme Kuruluşu'nun (IEA) "Uluslararası Okuma Becerileri Gelişim Projesi”" kapsamında yaptığı bir araştırmadır. 2001 yılında yapılan bu araştırmaya 35 ülkeden ilköğretim 4.sınıf öğrencileri katılmış. Araştırmanın Türkiye ayağı 62 ilin 154 ilköğretim okulundaki 5390 öğrenciyi ve bu öğrencilerin ailelerini, sınıf öğretmenlerini ve okul müdürlerini kapsamış. Öğrencilerin okuma ve kavrama becerilerinin yanı sıra yakın çevrenin çocukların okuma 
süreçlerine desteği de değerlendirilmiş. Araştırmanın sonuçları Türkiye'nin 35 ülke içinde 28. sırada olduğunu gösteriyor. Aile ortamında okuma etkinliklerine yer ayrılmadığını, evdeki kitap sayısının uluslararası ortalamaya göre oldukça düşük olduğunu, okuma çalışmalarının sadece ders kitaplarında bulunan metinlere dayalı olarak yürütüldüğünü, sınıf mevcutlarının çok kalabalık olduğunu, sınıfta çocuk kitaplarına, gazetelere ve dergilere dayalı etkinliklerin fazla yapılmadığını ve ölçme değerlendirmenin daha çok testlerden oluştuğunu söylüyor PIRLS sonuçları. Değerlendirmelerde hemen hemen her alanda İsveç'in ilk sırada yer aldığı, onun ardından Hollanda ve İngiltere'nin geldiği görülüyor. 15 yaş grubunun matematik, fen, sorun çözme ve okuma becerilerini kapsayan PISA genel başarı araştırmasında da durum pek farklı değil. Türkiye, 41 ülke içinde son sıralarda yer alıyor. PIRLS ve PISA araştırmaları, eğitim sistemimizin eksikliklerini gözler önüne seren araştırmalardan sadece ikisi.

Okumaz-yazmaz bir toplum olduğumuzu gösteren ulusal ya da uluslararası ölçekli pek çok araştırma, okuma kültürü kazandırma konusunda bir şeyler yapılması gerektiğinin işaretlerini vermektedir. Okuma ilgisi ve becerileri kazandırma yolunda pek başarılı olduğu söylenemeyen Türkçe ve edebiyat derslerinde farklı yaklaşımların denenmesinin eğitime yeni bir soluk getireceği düşünülmektedir. Bu düşünceden yola çıkarak, Türkiye Eğitim Gönülleri Vakfı (TEGV) çatısı altında Yapı Kredi Bankasının desteği ile bir yaratıcı okuma projesi hazırlanmıştır. "Okuyorum Oynuyorum" isimli proje, yaratıcı drama yöntemi ile desteklenen okuma sürecinin çocuklara okuma heyecanı kazandırabileceği ve çocukların okuma sürecine yönelik kaygıları varsa onları azaltacak eğlenceli ve etkili bir okuma ortamı yaratabileceği düşüncesinden yola çıkmaktadır. TEGV'in 34 ilde, 11 eğitim parkında ve 55 öğrenim biriminde uygulanmakta olan yaratıcı okuma programı Ağustos 2006'dan bu yana 37.822 çocuğa ulaşmıştır. Yaratıcı okuma programının, 2009 yılının sonunda 50 bin çocuğa ulaşması hedeflenmektedir.

Saplantılardan arınmış bir düşünme alışkanlığı kazandırmak; eleştirel bakışı uyandırmak; çok yönlü düşünmeyi öğretmek, düş gücünü geliştirmek yani bireyi işlevsel okur-yazar yapabilmek elbette çok daha uzun soluklu çalışmalar gerektirmektedir. Ancak, çocukların farkındalıklarını yükseltmelerine, bu farkındalıklarını ve yeni edindikleri becerilerini koruyabilmelerine, davranışa dönüştürebilmelerine yardım eden, oyunlarla ve yaratıcı drama teknikleriyle desteklenen yaratıcı okuma çalışmalarının çocukların kitaplara bakışını değiştirebilecek ve bu süreçten keyif almalarını sağlayacak çalışmalardan biri olduğu söylenebilir.

\section{Araştırmanın Amacı}


$\mathrm{Bu}$ çalışma, okuma-anlama sürecinin yaratıcı etkinliklerle desteklenmesinin çocuklara okuma kültürü kazandırma yolunda atılmış adımlardan biri olabileceği fikrinden yola çıkarak tasarlanmıştır. $\mathrm{Bu}$ araştırmanın temel amacı, yaratıcı drama ile desteklenen yaratıcı okuma programının çocukların okuma sürecine olan etkilerini belirlemektir.

\section{Yöntem}

$\mathrm{Bu}$ bölümde, çalışma grubu, veri toplama araçları ve verilerin analizinde kullanılacak istatiksel yöntem açıklanmaktadır.

\section{Çalışma Grubu}

Türkiye Eğitim Gönüllüleri Vakfı'nın (TEGV) 34 ilde (11 Eğitim Parkı ve 55 Öğrenim Birimi'nde) uygulanmakta olan "Okuyorum Oynuyorum” isimli yaratıcı okuma etkinliğine 20072008 güz ve bahar döneminde katılan, 9-13 yaş aralığındaki çocuklar içinden rasgele seçilen 258 çocuk (121 kız ve 137 erkek) bu çalışmanın örneklem grubunu oluşturmaktadır. Grubun cinsiyet ve yaşa göre dağılımı Tablo 1'de verilmiştir.

Tablo 1.

Cinsiyet ve Yaşa Göre Çocuk Sayısı

\begin{tabular}{lcccc}
\hline Yaș & & Kuz & Erkek & Toplam \\
\hline & 9 & 33 & 35 & $\mathbf{6 8}$ \\
& 10 & 40 & 37 & $\mathbf{7 7}$ \\
& 11 & 45 & 54 & $\mathbf{9 9}$ \\
& 12 & 3 & 7 & $\mathbf{1 0}$ \\
\hline Toplam & 13 & 0 & 4 & $\mathbf{4}$ \\
\hline
\end{tabular}

\section{Uygulama}

Uygulamalar, her hafta 1,5 saatlik oturumlar biçimde, 8 hafta sürmüştür. Ön-test ilk oturumun başlangıcında, son-test ise sekizinci oturumun bitiminde verilmiştir. Gruplar, her hafta başka bir metin (öykü, şiirler ya da resim) üzerinde çalışmış; sekiz haftanın sonunda her yaş grubu, en az 6 yazarın, 3 şairin ve bir ressamın yapıtlarıyla buluşmuştur.

Her oturum, çocukları, o oturumda ele alınacak yapıttaki konulara zihinsel ve bedensel olarak 1sındıracak ısınma oyunlarıyla başlamaktadır. Ardından okuma-anlama ve dinleme-anlama becerilerini geliştirecek, öyküde anlatılanları düşündürecek, sorgulatacak sorular, oyunlar ve yaratıcı drama etkinlikleri ile devam etmektedir. Çocuklar, oturum sonrasında, okuma dosyasındaki 
bilgilendirici metinlere (okunulan metnin konusuyla ilgili) ve kulüp çalışmalarına yönlendirilmektedir.

Eğitim programı yapılandırılırken, çocukların gerek okul içinde, gerekse okul dışında kitaplarla buluşmaları sürecinde yaşadıkları sorunlar dikkate alınmış, çocuklarda okuma heyecanı oluşturmak amacıyla her yapıt için yaratıcı drama yaklaşımının temelde olduğu yaratıcı okuma etkinlikleri hazırlanmıştır. Yaratıcı okuma çalışmalarında doğaçlama, dramatizasyon, rol oynama, ritim, öyküşiir-şarkı yazma, donuk imge, iç ses, film kareleri, bilinç koridoru, rol içinde yazma, telefon görüşmesi, televizyon programı, pandomim, geriye dönüş, maske-resim-heykel yapma gibi çalışmalara yer verilmiştir.

Çalışmaların uygulanması için TEGV eğitim parklarında yaratıcı okuma programına uygun olarak tasarlanan özel okuma mekanları kurulmuştur. "Okuma Adası” olarak adlandırılan bu okuma mekanlarında yaratıcı okuma etkinliklerini destekleyecek görsel uyaranlar (kostüm dolabı, hazine sandığı, kitaplık) yer almaktadır. Okuma Adası, ada çağrışımını yapan görsellerle dekore edilmiş, okunacak her yapıt için gerekli olan malzemeler hazine sandığ çalışmaların planlanması ve farklı eğitim noktalarında uygulanabilmesi için, programda yer alan 40 yapıtla ilgili bir rehber kitap hazırlanmıştır. TEGV çatısı altında "Okuyorum Oynuyorum" etkinliğini verecek eğitmenleri yetiştirmek üzere 104 eğitici eğitmenine eğitim verilmiştir.

Okuyorum Oynuyorum yaratıcı okuma programı, yaratıcı okuma sürecini öğretim yılına yayılan serbest çalışmalarla da -"Yerel Okuma Şenlikleri" ve "Sokak Tiyatrosu Şenlikleri”- desteklemiş, çocuklarla oturumlar dışında da buluşmuştur. Sokak Tiyatrosu Şenlikleri kapsamında, sekiz hafta boyunca kitaplarını okudukları yazarların tiyatro oyunlarıyla da buluşan çocuklar, profesyonel oyuncuların yönetmenliğinde yaklaşık üç ay süren provalar sonucunda oyunlarını hazırlamış ve halka açık bir şenlikte oyunlarını şehir meydanında sergilemiştir. Çocuklar sekiz hafta boyunca yaratıcı okuma programında kitaplarını okudukları yazarlarla Yerel Okuma Şenlikleri'nde de buluşmuş, onlarla söyleşiler ve okuma etkinlikleri yapmıştır. Yaratıcı okuma çalışmaları sekiz haftalık uygulamaların bitiminde kulüp çalışmalarıyla da desteklenmiştir. Kulüp çalışmaları, sanatsal uygulamaların (kitap ayracı, kitap posteri yapma vb) yanı sıra kitabın yolculuğunun içinde yer alan yerlere (matbaa, yayınevi, kitapçı vb) yapılan gezileri kapsamaktadır.

\section{Verilerin Toplanması}

Kullanılan ölçüm aracı, Okuyorum Oynuyorum etkinliklerinin hedeflerine ve içeriğine uygun olarak, TEGV eğitim departmanı ve araştırmacı (programın danışmanı ve içerik sorumlusu) tarafından çocukların okuma tutum ve davranışlarındaki değişimi belirlemek için hazırlanmıştır. Bu 
amaca yönelik olarak, etkinlik dönemi başında ve sonunda çocuklara anket uygulaması yapılmış ve yaratıcı okuma programının katılımı çocuklar üzerindeki etkisi araştırılmıştır.

Araştırmada “Çocuk Okuma Tutum Ölçeği” ölçüm aracı kullanılmıştır. Okuma tutum ve davranışları ile ilgili, çocuklar 30 ölçek maddesine "1'den (Kesinlikle Katılmıyorum), 4'e (Kesinlikle Katılıyorum)" kadar derecelendirilmiş bir ölçekte kendilerine uygun olan seçeneği işaretleyerek cevaplandırmışlardır.

Anket, "Yaratıcı Okuma", "Hoşlanma", "Kaygı" ve "Yeterlilik" olmak üzere dört alt boyuttan oluşmaktadır. Ankette yer alan soruların boyutlara dağılımı Tablo 2'de verilmektedir.

Tablo 2.

Ölçek sorularının alt boyutlara dă̆ılımı

\begin{tabular}{|l|l|}
\hline \multicolumn{1}{|c|}{ Alt boyut } & \multicolumn{1}{|c|}{ Soru Numarası } \\
\hline Yaratıcı Okuma & $10,12,16,17,20,21,22,23,24,16,27$ \\
\hline Hoşlanma & $3,5,7,8,9,11,13,14,15,18,30$ \\
\hline Kayg1 & $4,19,28$ \\
\hline Yeterlilik & $1,2,6,25,29$ \\
\hline
\end{tabular}

Okuma Tutum Ölçeği'nin güvenirliği Cronbach alfa iç tutarlılık katsayısı $(\alpha)$ kullanılarak belirlenmiştir. Buna göre ölçeğin $\alpha$ değeri .79 olarak bulunmuştur ve bu tipteki çalışmalar için yeterli kabul edilen $(\alpha \geq 0.70)$ değeri sağlamaktadır. Yaratıcı okuma, hoşlanma, kaygı ve yeterlilik alt boyutları için Cronbach alpha değerleri ise sırasıyla $.68, .71, .51$ ve .56 olarak bulunmuştur.

Okuma Tutum Ölçeği, Okuyorum Oynuyorum programına katılan çocuklara etkinlik dönemi başında ön-test; etkinlik dönemi sonunda da son-test olarak uygulanmış ve programın çocuklar üzerindeki etkisi araştırılmıştır. Önce çocukların okuma ile ilgili tutumlarındaki değişime genel olarak bakılmış, daha sonra da alt boyutlardaki değişimler incelenmiştir. Okuma Tutum Ölçeği kapsamında yer alan alt boyutlardaki sorularla, Okuyorum Oynuyorum programını alan çocukların yaratıcı okumanın yanı sıra okuma ile ilgili hoşlanma, kaygı ve yeterlilik gibi alt boyutlardaki tutumlarında da değişim olup olmadığı belirlemek için eşleştirilmiş t-testi kullanılarak, sözü edilen her bir alt boyut için analizler yapılmıştır. Sonuçlar her alt boyut için ayrı ayrı değerlendirilmiştir.

\section{Bulgular}

Okuma Tutumundaki genel değişimin ve alt boyutların -"Yaratıcı Okuma”, "Hoşlanma”, "Kaygı" ve "Yeterlilik"- analizi sonucunda elde edilen bulgular aşağıda verilmiştir.

\section{Okuma Tutumu (Toplam Puan)}


Okuma Tutum Ölçeğinde toplam 30 soru bulunmaktadır. Ölçekten alınabilecek en yüksek puan 120, en düşük puan 30'dur. Ölçekte bulunan 4, 7, 19, 20, 27 ve 28. sorular negatif anlam içerdiğinden toplam puanlar hesaplanırken bu soruların puanları ters çevrilmiştir. Okuma tutumu ön-test ve son-test toplam puanları için ortalamalar ve standart sapma değerleri Tablo 3 'te verilmektedir.

Tablo 3.

Okuma Tutumu Ön-test ve Son-test Ortalama Puanlarl ve Standart Sapmalar

\begin{tabular}{c|cc}
\hline & Ortalama Puan & Standart Sapma \\
\hline$\ddot{\text { On-test }}$ & 95,65 & 12,81 \\
\hline Son-test & 100,67 & 10,58 \\
\hline
\end{tabular}

Okuma Tutumu ön-test ve son-test puanlarındaki farklılık Grafik 1'de gösterilmektedir.

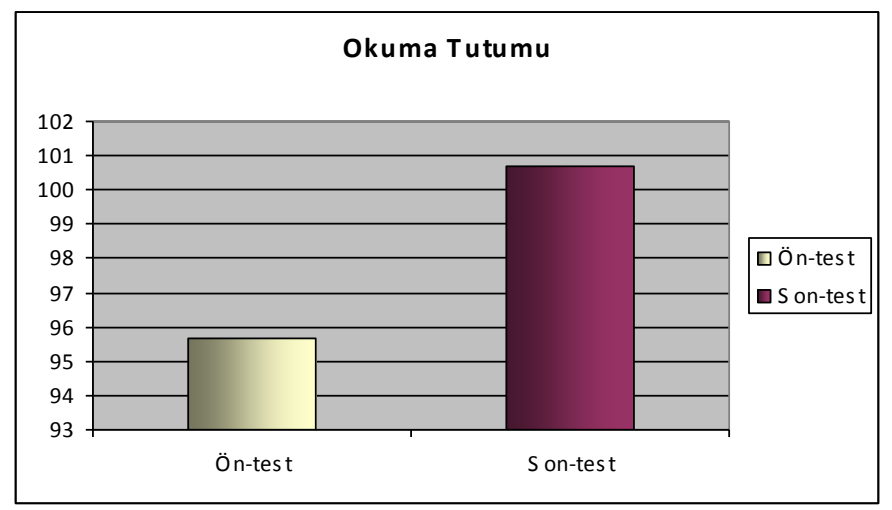

\section{Grafik 1.}

Okuma Tutumu Ön-test ve Son-test Toplam Puanlart

Okuma tutumu ölçeği, ön-test ve son-test toplam puanları ve Grafik 1 incelendiğinde, ortalama puanlarda artış olduğu, Okuyorum Oynuyorum etkinliği alan çocukların okuma tutumlarının olumlu yönde geliştiği görülmektedir.

Okuma tutumu ön-test ve son-test sonuçları arasında istatistiksel olarak anlamlı farklılık olup olmadığını belirlemek için eşleştirilmiş t-testi analizi yapılmıştır. Tablo 4'de verilen eşleştirilmiş ttesti sonuçları incelendiğinde ön-test ve son-test ortalama puanları arasındaki farkın istatistiksel olarak anlamlı olduğu da görülmektedir $(\mathrm{p}<.05)$.

Tablo 4.

Okuma tutumu -Eşleştirilmiş t-testi Sonuçları

$\begin{array}{lllll}\text { Ortalama } & \begin{array}{c}\text { Standart } \\ \text { Sapma }\end{array} & \text { t } & \text { df } & \text { Sig. }\end{array}$




\begin{tabular}{l|lllll} 
Son test-Ön test & 5,02 & 14,37 & 5,604 & 257 &, 000 \\
\hline
\end{tabular}

\section{Yaratıcı Okuma Alt Boyutu}

Yaratıcı Okuma alt boyutunda on bir soru bulunmaktadır. Bunlar:

- (10) Birisi bana öykü okurken ya da anlatırken kahramanların yerine geçerek ve sesini değiştirerek okursa hoşuma gider.

- (12) Kitap okurken kendimi kitap kahramanlarının yerine koyar, onların seslerini taklit ederek kitap okumaya çalışırım.

- (16) Okuduğum bir öyküde anlatılanları hayal ederim.

- (17) Okuduğum bir öyküden yola çıkarak yeni öyküler uydurmaktan hoşlanırım.

- (20) Okuduğum öyküleri arkadaşlarıma anlatmayı sevmem.

- (21) Okuduğum öyküyle ilgili yazı yazmayı severim.

- (22) Okuduğum ya da dinlediğim bir öykünün nasıl biteceğini hayal etmeye çalışırım.

- (23) Okuduklarımı arkadaşlarımla birlikte canlandırmak hoşuma gider.

- (24) Okuduklarımla ilgili resim çizmeyi severim.

- (26) Okurken gözümün önünde canlanan şeyleri arkadaşlarıma anlatmayı severim.

- (27) Oyun zamanı ayrı, kitap okuma zamanı ayrıdır, ikisi aynı anda yapılmaz.

Yaratıcı Okuma alt boyutundan alınabilecek en düşük puan 11, en yüksek puan ise 44'tür. Bu alt boyutta bulunan 20 ve 27. sorular negatif anlam içerdiğinden toplam puanlar hesaplanırken bu soruların puanları ters çevrilmiştir. Yaratıcı Okuma alt boyutu ön-test ve son-test toplam puanları için ortalamalar ve standart sapma değerleri Tablo 5'te verilmektedir.

Tablo 5.

Yaratıcı Okuma Alt Boyutu Ön-test ve Son-test Ortalama Puanlarl ve Standart Sapmalar

\begin{tabular}{c|cc}
\hline & Ortalama Puan & Standart Sapma \\
\hline Ön-test & 33,84 & 5,87 \\
\hline Son-test & 35,95 & 4,60 \\
\hline
\end{tabular}

Yaratıcı Okuma alt boyutunun ön-test ve son-test puanlarındaki farklılık Grafik 2'de gösterilmektedir. 


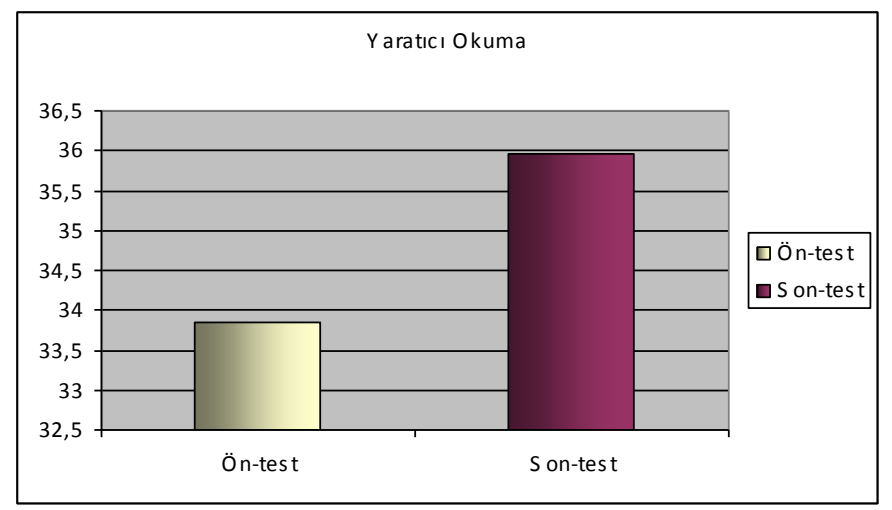

Grafik 2.

Yaratıcı Okuma Alt Boyutu Ön-test ve Son-test Toplam Puanlart

Yaratıcı Okuma alt boyutu ön-test ve son-test toplam puanları ve Grafik 2 incelendiğinde, ortalama puanlardaki artış olduğu, Okuyorum Oynuyorum etkinliği alan çocukların yaratıcı okuma alanı ile ilgili tutumlarının olumlu yönde geliştiği görülmektedir.

Yaratıcı Okuma alt boyutu ön-test ve son-test sonuçları arasında istatistiksel olarak anlamlı farklılık olup olmadığını belirlemek için eşleştirilmiş t-testi analizi yapılmıştır. Tablo 6' da verilen eşleştirilmiş t-testi sonuçları incelendiğinde ön-test ve son-test ortalama puanları arasındaki farkın istatistiksel olarak anlamlı olduğu da görülmektedir $(p<.05)$.

Tablo 6.

Yaratıcı Okuma -Eşleştirilmiș t-testi Sonuçları

\begin{tabular}{c|ccccc}
\hline & Ortalama & $\begin{array}{c}\text { Standart } \\
\text { Sapma }\end{array}$ & t & df & Sig. \\
\hline Son test-Ön test & 2,11 & 6,44 & 5,279 & 257 &, 000 \\
\hline
\end{tabular}

Yaratıc1 Okuma alt boyutunda yer alan 10,12, 17, 23 ve 27. sorular programdaki uygulamalarla doğrudan ilgilidir. Okuyorum Oynuyorum programında, kitapları öykü anlatma (storytelling) tekniklerine uygun olarak eğitmenler okumakta, öykülerin alt metinleri yaratıcı drama etkinlikleri ile genişletilerek ele alınmakta ve çocuklardan dinledikleri öykülerden yola çıkarak yeni öyküler oluşturmaları istenmektedir. $\mathrm{Bu}$ nedenle Yaratıcı Okuma alt boyutunda yer alan bu soruların, programın yapılandırıldığı yöntemle ilgili ana noktaları kapsadığı için, diğerlerine oranla daha dikkate değer olduğu söylenebilir. Tablo 7'de Yaratıcı Okuma alt boyutunun 10, 12, 17, 23 ve 27. sorularının ön-test ve son-test puanları için ortalamalar ve standart sapma değerleri verilmektedir. 
Tablo 7.

Yaratıcı Okuma Alt Boyutu 10, 12, 17, 23 ve 27. Sorular Ön-test ve Son-test Ortalama Puanlart ve Standart Sapmalar

\begin{tabular}{c|ccc}
\hline & & Ortalama Puan & Standart Sapma \\
\hline Soru 10 & On-test & 3,33 &, 969 \\
& Son-test & 3,60 &, 706 \\
Soru 12 & On-test & 3,15 & 1,048 \\
& Son-test & 3,39 &, 839 \\
& On-test & 3,04 & 1,105 \\
\multirow{2}{*}{ Soru 23 } & Son-test & 3,27 &, 930 \\
\multirow{2}{*}{ Soru 27 } & On-test & 3,51 &, 918 \\
& Son-test & 3,58 &, 752 \\
& On-test & 1,54 &, 968 \\
\hline & Son-test & 1,76 & 1,098 \\
\hline
\end{tabular}

Yaratıcı Okuma alt boyutu 10,12, 17, 23 ve 27. sorularının ön-test ve son-test puanlarındaki farkl111k Grafik 3’te gösterilmektedir.

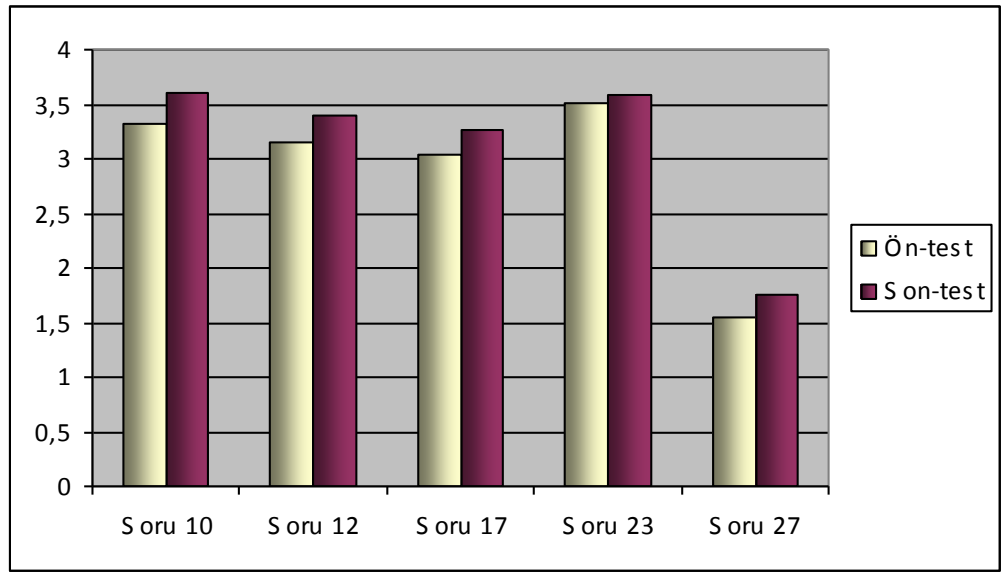

\section{Grafik 3.}

Yaratıcı Okuma Alt Boyutu 10, 12, 17, 23 ve 27. Sorular Ön-test ve Son-test Puanlarl

Yaratıcı Okuma alt boyutunda yer alan 10,12, 17, 23 ve 27. soruların ön-test ve son-test puanları ve Grafik 3 incelendiğinde, bu soruların tümünün ortalama puanlarında artış olduğu, Okuyorum Oynuyorum programını alan çocukların, yaratıcı okuma ile ilgili etkinliklerde yer verilen ve özellikle geliştirilmesi hedeflenen noktalarda olumlu değişim gösterdikleri görülmektedir.

$10,12,17,23$ ve 27 . soruların ön-test ve son-test sonuçları arasında istatistiksel olarak anlamlı farklılık olup olmadığını belirlemek için eşleştirilmiş t-testi analizi yapılmıştır. Tablo 8'de verilen eşleştirilmiş t-testi sonuçları incelendiğinde ön-test ve son-test ortalama puanları arasındaki farkın, 23. soru hariç, diğer sorular için istatistiksel olarak anlamlı olduğu da görülmektedir $(\mathrm{p}<.05)$. 
Tablo 8.

Yaratıcı Okuma Alt Boyutu 10, 12, 17, 23 ve 27. Sorular -Eşleştirilmiş t-testi Sonuçları

\begin{tabular}{l|ccccc}
\hline & Ortalama & Standart Sapma & t & df & Sig. \\
\hline Son test-Ön test (Soru 10) &, 272 & 1,157 & 3,773 & 256 &, 000 \\
Son test-Ön test (Soru 12) &, 239 & 1,191 & 3,207 & 254 &, 002 \\
Son test-Ön test (Soru 17) &, 229 & 1,292 & 2,822 & 252 &, 005 \\
Son test-Ön test (Soru 23) &, 072 & 1,093 & 1,039 & 250 &, 300 \\
\hline Son test-Ön test (Soru 27) &, 220 & 1,355 & 2,546 & 244 &, 012 \\
\hline
\end{tabular}

Tablo 9'da Yaratıcı Okuma alt boyutunun diğer sorularının -16, 20, 21, 22, 24 ve 26- ön-test ve son-test puanları için ortalamala ve standart sapma değerleri verilmektedir.

Tablo 9.

Yaratıcı Okuma Alt Boyutu 16, 20, 21, 22, 24 ve 26. Sorular Ön-test ve Son-test Ortalama Puanlart ve Standart Sapmalar

\begin{tabular}{c|ccc}
\hline & & Ortalama Puan & Standart Sapma \\
\hline Soru 16 & On-test & 3,36 &, 932 \\
& Son-test & 3,52 &, 735 \\
Soru 20 & On-test & 2,66 & 1,289 \\
& Son-test & 2,99 & 1,221 \\
& On-test & 3,20 & 1,033 \\
\multirow{2}{*}{ Soru 22 } & Son-test & 3,34 &, 904 \\
& On-test & 3,34 &, 982 \\
\multirow{2}{*}{ Soru 24 } & Son-test & 3,55 &, 733 \\
\multirow{2}{*}{ Soru 26 } & On-test & 3,35 &, 988 \\
& Son-test & 3,51 &, 817 \\
& On-test & 3,26 &, 982 \\
\hline & Son-test & 3,37 &, 909 \\
\cline { 2 - 3 } & & & \\
\hline
\end{tabular}

Yaratıcı Okuma alt boyutu 16, 20, 21, 22, 24 ve 26. sorularının ön-test ve son-test puanlarındaki farklılık Grafik 4'te gösterilmektedir. 


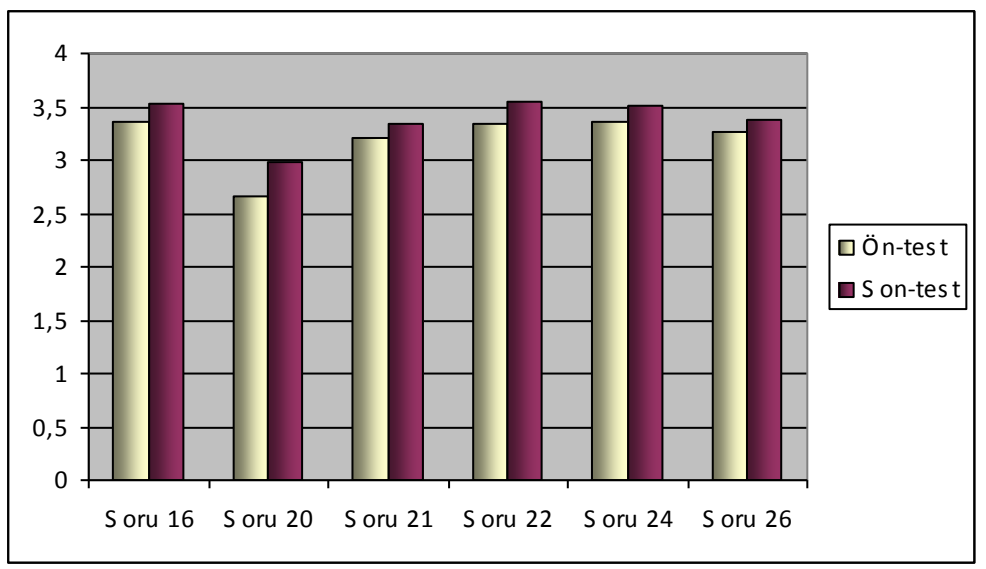

\section{Grafik 4.}

Yaratıcı Okuma Alt Boyutu 16, 20, 21, 22, 24 ve 26. Sorular Ön-test ve Son-test Puanlarl

Yaratıcı Okuma alt boyutunda yer alan 16, 20, 21, 22, 24 ve 26. soruların ön-test ve son-test puanları ve Grafik 4 incelendiğinde, bu soruların tümünün ortalama puanlarında artış olduğu görülmektedir.

$16,20,21,22,24$ ve 26. soruların ön-test ve son-test sonuçları arasında istatistiksel olarak anlamlı farklılık olup olmadığını belirlemek için eşleştirilmiş t-testi analizi yapılmıştır. Tablo 10'da verilen eşleştirilmiş t-testi sonuçları incelendiğinde ön-test ve son-test ortalama puanları arasındaki farkın, 26. soru hariç diğer sorular için istatistiksel olarak anlamlı olduğu da görülmektedir $(\mathrm{p}<.05)$.

\section{Tablo 10.}

Yaratıcı Okuma Alt Boyutu 16, 20, 21, 22, 24 ve 26. Sorular -Eşleştirilmiş t-testi Sonuçları

\begin{tabular}{l|ccrcc}
\hline & Ortalama & Standart Sapma & t & df & Sig. \\
\hline Son test-Ön test (Soru 16) &, 165 & 1,093 & 2,377 & 248 &, 018 \\
Son test-Ön test (Soru 20) &, 332 & 1,725 & 3,061 & 252 &, 002 \\
Son test-Ön test (Soru 21) &, 135 & 1,175 & 1,826 & 250 &, 069 \\
Son test-Ön test (Soru 22) &, 208 & 1,089 & 3,021 & 249 &, 003 \\
Son test-Ön test (Soru 24) &, 155 & 1,154 & 2,133 & 250 &, 034 \\
\hline Son test-Ön test (Soru 26) &, 109 & 1,187 & 1,444 & 247 &, 150 \\
\hline
\end{tabular}

\section{Hoșlanma Alt Boyutu}

Hoşlanma alt boyutunda 11 soru bulunmaktadır. Bunlar:

- (3) Arkadaşlarımla kitaplar hakkında konuşup tartışmaktan hoşlanırım.

- (5) Başka birisinin bana kitap okuması hoşuma gider. 
- (7) Bence kitap okumak çok sıkıcıdır.

- (8) Bence kitap okumak eğlencelidir.

- (9) Bence kitap okumak heyecan vericidir.

- (11) Kitap okumayı severim.

- (13) Kitapların resimlerine bakmaktan hoşlanırım.

- (14) Kütüphaneye gitmeyi severim.

- (15) Okuduğum bir kitabı sevdiysem birkaç kez okurum.

- (18) Okuduğum kitapları çevremdekilere anlatmayı severim.

- (30) Şiir okumayı severim.

Hoşlanma alt boyutundan alınabilecek en düşük puan 11, en yüksek puan ise 44'tür. Bu alt boyutta bulunan 7. soru negatif anlam içerdiğinden toplam puanlar hesaplanırken puanı ters çevrilmiştir. Hoşlanma alt boyutu ön-test ve son-test toplam puanları için ortalamalar ve standart sapma değerleri Tablo 11'de verilmektedir.

Tablo 11.

Hoşlanma Alt Boyutu Ön-test ve Son-test Ortalama Puanlart ve Standart Sapmalar

\begin{tabular}{c|cc}
\hline & Ortalama Puan & Standart Sapma \\
\hline Ön-test & 37,25 & 6,04 \\
\hline Son-test & 38,27 & 4,49 \\
\hline
\end{tabular}

Hoşlanma alt boyutunun ön-test ve son-test puanlarındaki farklılık Grafik 5'te gösterilmektedir.

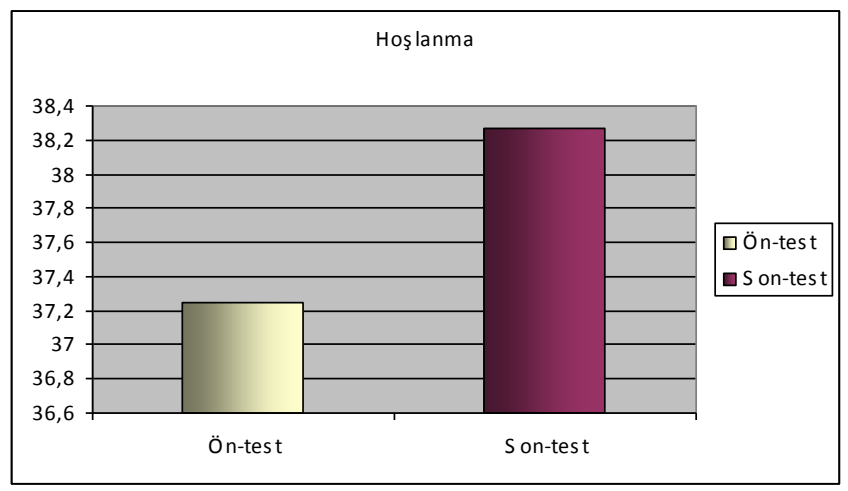

\section{Grafik 5.}

Hoşlanma Alt Boyutu Ön-test ve Son-test Toplam Puanlarl 
Hoşlanma alt boyutu, ön-test ve son-test toplam puanları ve Grafik 5 incelendiğinde, ortalama puanlarda artış olduğu, Okuyorum Oynuyorum programını alan çocukların okuma sürecinden daha fazla hoşlanmaya başladıkları görülmektedir.

Hoşlanma alt boyutu, ön-test ve son-test sonuçları arasında istatistiksel olarak anlamlı farklılık olup olmadığını belirlemek için eşleştirilmiş t-testi analizi yapılmıştır. Tablo 12'de verilen eşleştirilmiş t-testi sonuçları incelendiğinde ön-test ve son-test ortalama puanları arasındaki farkın istatistiksel olarak anlamlı olduğu da görülmektedir $(p<.05)$.

\section{Tablo 12.}

Hoşlanma -Eşleştirilmiş t-testi Sonuçları

\begin{tabular}{c|ccccc}
\hline & Ortalama & $\begin{array}{c}\text { Standart } \\
\text { Sapma }\end{array}$ & t & df & Sig. \\
\hline Son test-Ön test & 1,02 & 6,53 & 2,50 & 257 &, 013 \\
\hline
\end{tabular}

Hoşlanma alt boyutunda yer alan 5 ve 8 . sorular programın hedefleriyle doğrudan ilişkilidir. Okuyorum Oynuyorum programında yer alan yaratıcı okuma etkinliklerinde çocuklar yapıtları okumamakta, yapıtlar onlara eğitmen tarafindan okunmaktadır. Çünkü, yaratıcı okuma programı, okuma sürecinin eğlenceli bir etkinlik olduğunu çocuklara hissettirebilmek için öykü anlatma tekniklerine (storytelling) göre yapılandırılmış bir programdır. Bu nedenle Hoşlanma alt boyutu içinde, çocukların yukarıda sözü edilen iki soruya verdikleri yanıtlardaki değişim önem kazanmaktadır. Tablo 13'te Yaratıcı Okuma alt boyutunun 5. ve 8. sorularının ön-test ve son-test puanları için ortalamalar ve standart sapma değerleri verilmektedir.

Tablo 13.

Hoşlanma Alt Boyutu 5 ve 8 Sorular Ön-test ve Son-test Ortalama Puanlarl ve Standart Sapmalar

\begin{tabular}{|c|c|c|c|}
\hline & & Ortalama Puan & Standart Sapma \\
\hline \multirow[t]{2}{*}{ Soru 5} & $\ddot{O} n$-test & 3,39 & ,984 \\
\hline & Son-test & 3,49 & ,790 \\
\hline \multirow[t]{2}{*}{ Soru 8} & $\ddot{O} n$-test & 3,50 & 900 \\
\hline & Son-test & 3,65 & ,711 \\
\hline
\end{tabular}

Hoşlanma alt boyutu 5. ve 8. soruların ön-test ve son-test puanlarındaki farklılık Grafik 6'da gösterilmektedir. 


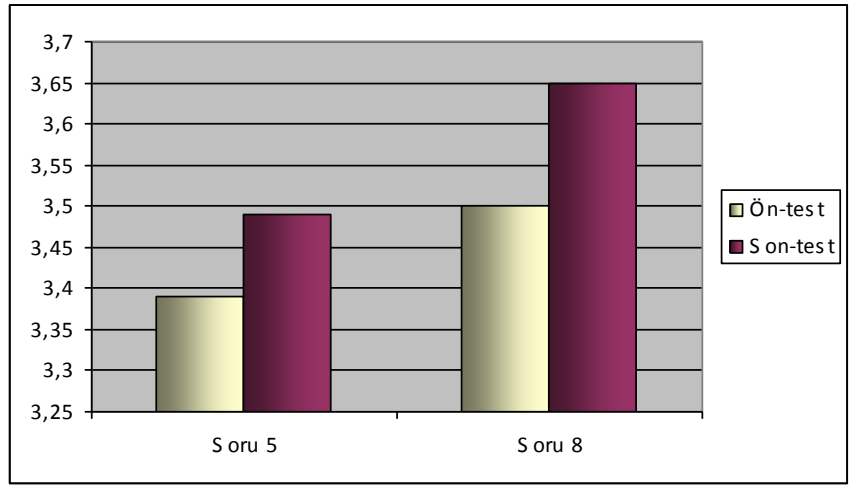

\section{Grafik 6.}

Hoşlanma Alt Boyutu 5 ve 8. Sorular Ön-test ve Son-test Puanlart

Hoşlanma alt boyutunda yer alan 5. ve 8. soruların ön-test ve son-test puanları ve Grafik 6 incelendiğinde, bu soruların ortalama puanlarında artış olduğu, Okuyorum Oynuyorum programına katılan çocukların, yaratıcı okuma etkinliklerinde yer verilen ve özellikle geliştirilmesi hedeflenen noktalarda olumlu değişim gösterdikleri görülmektedir.

5. ve 8. soruların ön-test ve son-test sonuçları arasında istatistiksel olarak anlamlı farklılık olup olmadığını belirlemek için eşleştirilmiş t-testi analizi yapılmıştır. Tablo 14'de verilen eşleştirilmiş ttesti sonuçları incelendiğinde, 5. sorunun ön-test ve son-test puanları arasındaki farkın istatistiksel olarak anlamlı olmadığı $(\mathrm{p}>.05), 8$. sorunun ön-test ve son-test puanları arasındaki farkın istatistiksel olarak anlamlı olduğu görülmektedir $(\mathrm{p}<.05)$.

Tablo 14.

Hoşlanma Alt Boyutu 5 ve 8. Sorular-Eşleştirilmiş t-testi Sonuçları

\begin{tabular}{l|ccccc}
\hline & Ortalama & Standart Sapma & t & df & Sig. \\
\hline Son test-Ön test (Soru 5) &, 103 & 1,243 & 1,315 & 252 &, 190 \\
\hline Son test-Ön test (Soru 8) &, 149 & 1,051 & 2,265 & 254 & \multirow{2}{*}{024} \\
\hline
\end{tabular}

\section{Kaygi Alt Boyutu}

Kaygı alt boyutunda 3 soru bulunmaktadır. Bunlar:

- (4) Bana okuduklarımla ilgili soru sorulmasından çekinirim.

- (19) Okuduğum kitaplarla ilgili soruları yanlış cevaplamaktan korkarım.

• (28) Öyküleri arkadaşlarımın önünde yüksek sesle okumaktan hoşlanmam. 
Kayg1 alt boyutundan alınabilecek en düşük puan 3, en yüksek puan ise 12'dir. Kayg1 alt boyutu ön-test ve son-test toplam puanları için ortalamalar ve standart sapma değerleri Tablo 15 'de verilmektedir.

Tablo 15.

Kaygl Alt Boyutu Ön-test ve Son-test Ortalama Puanlarl ve Standart Sapmalar

\begin{tabular}{c|cc}
\hline & Ortalama Puan & Standart Sapma \\
\hline$\ddot{\text { Onn-test }}$ & 7,39 & 2,64 \\
\hline Son-test & 6,28 & 2,54 \\
\hline
\end{tabular}

Kayg1 alt boyutunun ön-test ve son-test puanlarındaki farklılık Grafik 7'de gösterilmektedir.

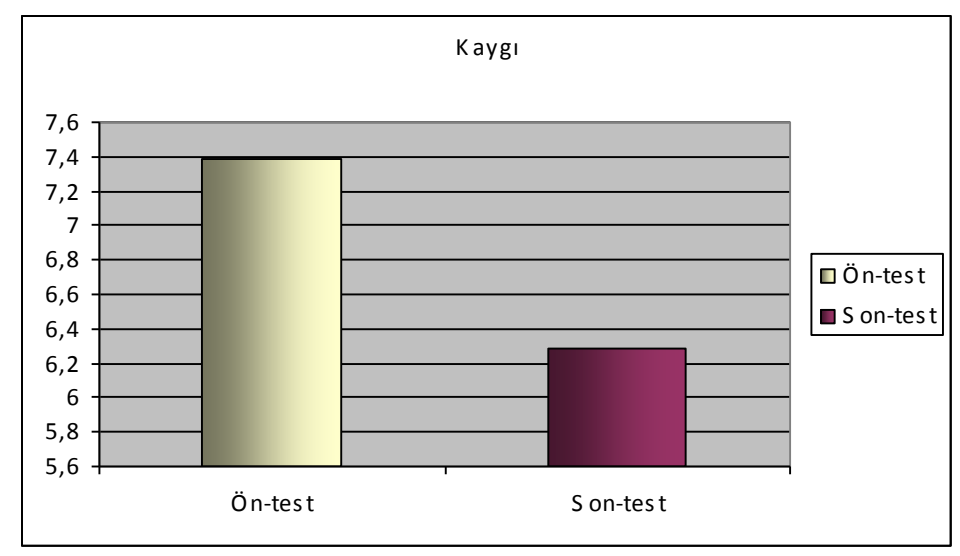

\section{Grafik 7.}

Kaygı Alt Boyutu Ön-test ve Son-test Toplam Puanlarl

Kaygı alt boyutu ön-test ve son-test toplam puanları ve Grafik 7 incelendiğinde, ortalama puanlarda düşüş olduğu, Okuyorum Oynuyorum programını alan çocukların okuma sürecindeki kaygılarının azaldı̆̆ı görülmektedir.

Kaygı alt boyutu ön-test ve son-test sonuçları arasında istatistiksel olarak anlamlı farklılık olup olmadığını belirlemek için eşleştirilmiş t-testi analizi yapılmıştır. Tablo 16 ' da verilen eşleştirilmiş ttesti sonuçları incelendiğinde ön-test ve son-test ortalama puanları arasındaki farkın istatistiksel olarak anlamlı olduğu da görülmektedir $(\mathrm{p}<.05)$.

\section{Tablo 16.}

Kaygl -Eşleştirilmiş t-testi Sonuçları 


\begin{tabular}{c|ccccc}
\hline & \multicolumn{5}{|c}{ Sapma } \\
\hline Son test-Ön test & $-1,10$ & 3,84 & $-4,611$ & 257 &, 000 \\
\hline
\end{tabular}

\section{Yeterlilik Alt Boyutu}

Yeterlilik alt boyutunda 5 soru bulunmaktadır. Bunlar:

- (1) Arkadaşlarım kadar iyi okuyorum.

- (2) Arkadaşlarımın yanında okuma parçalarını yüksek sesle okumaktan çekinmem.

- (6) Başkası okurken onu takip etmekte zorlanmam.

- (25) Okumak bana zor gelmez.

- (29) Sınıfta okuma parçalarını okumayı isterim.

Yeterlilik alt boyutundan alınabilecek en düşük puan 5, en yüksek puan ise 55'tir. Yeterlilik alt boyutu ön-test ve son-test toplam puanları için ortalamalar ve standart sapma değerleri Tablo 17'de verilmektedir

Tablo 17.

Yeterlilik Alt Boyutu Ön-test ve Son-test Ortalama Puanlart ve Standart Sapmalar

\begin{tabular}{c|cc}
\hline & Ortalama Puan & Standart Sapma \\
\hline Ön-test & 17,16 & 3,00 \\
\hline Son-test & 17,73 & 2,35 \\
\hline
\end{tabular}

Yeterlilik alt boyutunun ön-test ve son-test puanlarındaki farklılık Grafik 7'de gösterilmektedir.

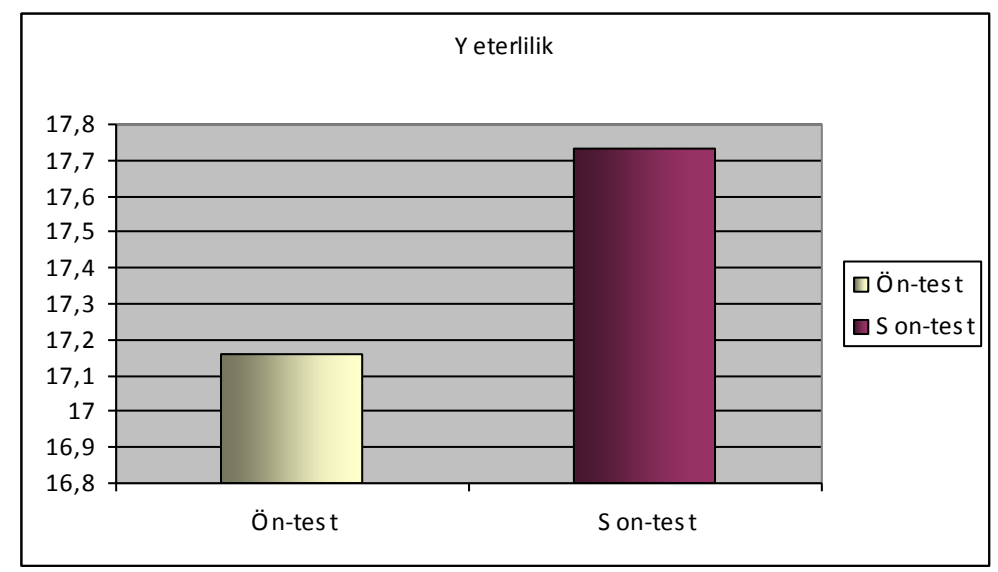

\section{Grafik 8.}

Yeterlilik Alt Boyutu Ön-test ve Son-test Toplam Puanlarl 
Yeterlilik alt boyutu ön-test ve son-test toplam puanları ve Grafik 8 incelendiğinde, ortalama puanlarda az da olsa bir artış olduğu, Okuyorum Oynuyorum programını alan çocukların okuma sürecinde kendilerini daha yeterli hissettikleri görülmektedir.

Yeterlilik alt boyutu ön-test ve son-test sonuçları arasında istatistiksel olarak anlamlı farklılık olup olmadığını belirlemek için eşleştirilmiş t-testi analizi yapılmıştır. Tablo 17'de verilen eşleştirilmiş t-testi sonuçları incelendiğinde ön-test ve son-test ortalama puanları arasındaki farkın istatistiksel olarak anlamlı olduğu da görülmektedir $(p<.05)$.

Tablo 18.

Hoşlanma -Eşleştirilmiş t-testi Sonuçları

\begin{tabular}{c|ccccc}
\hline & Ortalama & $\begin{array}{c}\text { Standart } \\
\text { Sapma }\end{array}$ & t & df & Sig. \\
\hline Son test-Ön test &, 562 & 3,59 & 2,513 & 257 &, 013 \\
\hline
\end{tabular}

\section{Bulgular ve Yorum}

$\mathrm{Bu}$ bölümde, elde edilen sonuçların yorumlarına yer verilmiştir.

\section{Yaraticı Okuma Alt Boyutu}

Yaratıcı Okuma bölümünde, yaratıcı etkinliklerle desteklenen okuma sürecinin çocukların okuma tutumlarında değişiklik yapıp yapmadığını ortaya koymak üzere on bir soru sorulmuştur. Bu sorular, çocukların sekiz hafta boyunca öykü anlatma (storytelling) tekniklerinin kullanılarak okunduğu öykülerin dinlenmesi, öykülerin konusuyla ya da iletisiyle ilgili oyunların oynanması, okuma-anlama çalışmalarının yapılması, öykülerin canlandırılması, öykülerden yola çıkarak başka öykülerin oluşturulması, yaratıcı yazma çalışmalarının yapılması gibi etkinliklerle ilgili yaklaşımlarını ortaya çıkarmak için sorulmuştur. Çocukların uygulama öncesinde ve sekiz hafta sonrasında verdiği yanıtlar karşılaştırıldığında, çocukların yaratıcı okuma süreci ile ilgili tutumlarının olumlu yönde geliştiği görülmektedir. Bir başka deyişle, çocukların öykü anlatma tekniği ile kendilerine okunan öyküleri dinlemekten keyif aldıkları, öyküleri dinlerken öyküyü gözlerinin önünde canlandırdıkları ve canlandırdıkları öyküleri resimlemeyi sevdikleri, öyküleri kendilerini kahramanların yerine koyarak ve seslerini değiştirerek okumak istedikleri görülmektedir. Özellikle oyun zamanı ve okuma zamanının ayrı şeyler olduğunu düşünen çocukların sekiz hafta sonunda bu tutumlarını değiştirmeleri dikkate değer bir noktadır. Sınıf, ev, kütüphane gibi geleneksel okuma ortamlarında ve sessiz okuma, bireysel okuma-anlama vb çalışmaları yaptıkları durumlarda çocukların okuma etkinliklerine ilişkin geliştirdikleri tutumların, yaratıcı okuma etkinlikleriyle desteklenen okuma sürecindeki kazanımları sonrasında 
değişebileceğini ve çocukların okuma ve oyunun aynı ortamda da gerçekleşebileceğini düşünmelerine yol açabileceğini göstermektedir. $\mathrm{Bu}$ bölümde yer alan, "okuduklarımı arkadaşlarımla birlikte canlandırmak hoşuma gider" maddesinde istatiksel olarak "anlamlı" bir değişime rastlanamaması dikkat çekmektedir. Buna ek olarak, “okurken gözümün önünde canlanan şeyleri arkadaşlarıma anlatmayı severim" maddesinde de anlamlı bir değişim söz konusu değildir. $\mathrm{Bu}$ verilerden yola çıkarak, sekiz haftalık sürenin (12 saat) grup etkileşimi oluşturmak için yeterli olmadığını, çocukların öyküleri hayal etmekten hoşlansalar da (soru 16 ve soru 22) hayal ettiklerini diğerleriyle paylaşmayı tercih etmediklerini söyleyebiliriz.

\section{Hoşlanma Alt Boyutu}

Hoşlanma alt boyutunu sorgulayan on bir soru, yaratıcı okuma programının çocukların okuma süreciyle ilgili beğenilerine olan etkilerini belirlemek için sorulmuştur. Çocukların uygulama öncesinde ve sekiz hafta sonrasında verdiği yanıtlar karşılaştırıldığında, Okuyorum Oynuyorum programını alan çocukların okuma sürecinden daha fazla hoşlanmaya başladıkları görülmektedir. Bir başka deyişle, veriler, çocukların kütüphaneye daha çok gitmek istediklerini, sevdikleri kitapları birkaç kez okumaktan, okuduklarını arkadaşlarıyla paylaşmaktan ve tartışmaktan daha çok hoşlanmaya başladıklarını göstermektedir.

Hoşlanma alt boyutunda yer alan 5. ve 8. sorular Okuyorum Oynuyorum programının hedefleriyle doğrudan ilişkilidir. Okuyorum Oynuyorum etkinliklerindeki öyküler, çocuklara öykü anlatma teknikleri dikkate alınarak okunmaktadır ve yaratıcı okuma etkinliklerinin amaçlarından birisi de öykü okumanın (storytelling) eğlenceli bir etkinlik olduğunu çocuklara duyumsatmaktır. Bu nedenle Hoşlanma alt boyutu içinde, çocukların yukarıda sözü edilen iki soruya verdikleri yanıtların değişimi önem kazanmaktadır.

"Bence kitap okumak eğlencelidir" maddesindeki (soru 8) değişim, yaratıcı okuma boyutunda yer alan, oyun zamanı ve okuma zamanının ayrı şeyler olduğunu söyleyen diğer maddedeki (soru 27) anlamlı değişim ile örtüşen bir durumdur. Çocukların kitap okumanın eğlenceli bir iş olduğunu söylemeye başlamaları yaratıcı okuma programının çocuklar üzerinde bıraktığı etkiyi göstermesi açısından önemli bir noktadır. PISA araştırmasının sonuçlarına bakılır ve Türkiye'deki çocuklar için, okuma çalışmalarının ders çalışma ile eş anlama geldiği, okuma-anlama becerilerinin testlerle ölçüldügüü ve çocukların ders kitapları dışında başka metinlerle karşılaşma fırsatının pek bulunmadığ1 düşünülürse, Okuyorum Oynuyorum programının, okuma kültürü kazanma yolunda çocuklara ilk adımı atmaları için bir firsat ve ortam yaratmış olduğu görülecektir.

Hoşlanma boyutunda yer alan "başka birisinin bana kitap okuması hoşuma gider" maddesinde (soru 5) istatiksel açıdan anlamlı bir değişikliğe rastlanılmamış olması, çocukların öyküleri 
başkasından dinlemeyi değil de bizzat okumak istediklerini göstermektedir. $\mathrm{Bu}$ istek, yaratıcı okuma boyutunda yer alan "birisi bana öykü okurken ya da anlatırken kahramanların yerine geçerek ve sesini değiştirerek okursa hoşuma gider" maddesindeki (soru 10) anlamlı değişim ile çelişiyor gibi görünse de, bu durum, çocukların okuma sürecine yönelik gelişen heyecanlarının bir göstergesi olarak ele alınırsa, anlamlı bir değişime rastlanılmamış olması 'olumlu' bir gelişme olarak da yorumlanabilir. Ve bu düşünceden yola çıkarak, çocukların öyküleri bir başkasından dinlemek yerine kendi başlarına okumak istemelerinin okuma sürecine yönelik geliştirilen olumlu bir değişim olduğunu destekleyen göstergeler şöyle sıralanabilir: Yaratıcı okuma programının uygulanmaya başlaması ile, Ağustos 2006'dan beri, TEGV eğitim parkları ve öğrenim birimlerindeki kütüphanelerde ya da kitaplıklarda hareketliliğinin artması, ödünç kitap almada görünen genel artış, etkinliklerde okunan kitapların etkinlik sonrasında hemen kütüphaneden ödünç alınmak istenmesi, çocukların öykü anlatma teknikleri ile dinledikleri öyküleri öykü anlatma (storytelling) tekniklerine göre okuma isteğinde bulunmaları vb.

Kısacası, bütün bu göstergeler ve elde edilen sonuçlar, Okuyorum Oynuyorum programına katılan çocukların, sekiz hafta sonunda, kitap okuma sürecinden daha fazla hoşlanmaya başlamaları olarak yorumlanabilir.

\section{Kaygı Alt Boyutu}

Kaygı alt boyutunda yer alan üç soru yaratıcı okuma programının çocukların okuma sürecinde yaşadıkları kaygıların azalmasında etkili olup olmadığııı belirlemektir. Kaygı alt boyutunun verileri incelendiğinde, Okuyorum Oynuyorum programına katılan çocukların yaratıcı okuma etkinlikleriyle tanışmadan önce sahip olduğu kaygı düzeylerinin sekiz hafta sonra azaldığ görülmektedir. Bir başka deyişle, veriler, çocukların soruları yanlış yanıtlamaktan çekindiklerini ve grup önünde konuşmak ya da okumaktan pek hoşlanmadıklarını, ancak yaratıcı okuma programındaki uygulamalardan sonra bu kaygılarında istatiksel açıdan anlamlı azalma olduğunu göstermektedir.

\section{Yeterlilik Alt Boyutu}

Yeterlilik alt boyutunda, yaratıcı etkinliklerle desteklenen okuma programının çocukların okuma sürecindeki yeterliliklerinde değişiklik yapıp yapmadığını belirlemek üzere beş soru sorulmuştur. Çocukların uygulama öncesinde ve sekiz hafta sonrasında verdiği yanıtlar karşılaştırıldığında, Okuyorum Oynuyorum programını alan çocukların yeterliliklerinde istatiksel açıdan anlamlı gelişmelerin olduğu görülmektedir. Bir başka deyişle, çocukların başkasının yanında kitap okuma 
ve okunanları takip etme konusunda gelişim gösterdikleri ve okuma sürecinde kendilerini daha yeterli hissettikleri söylenebilir.

Sonuç olarak, otuz soruluk Okuma Tutum Ölçeği'nin verilerine göre, yaratıcı okuma programına katılan çocukların okuma tutumlarının olumlu yönde geliştiği görülmektedir. Sonuçlara alt boyutlar kapsamında bakıldığında, çocukların kitaplardan ve okuma-anlama etkinliklerinden daha fazla hoşlanmaya başladıkları, okuma süreci ile ilgili kaygılarının azaldığg ve okuma konusunda kendilerini daha yeterli görmeye başladıkları görülmektedir. Ayrıca, Yaratıcı Okuma ve Hoşlanma alt boyutlarında, yaratıcı okuma programının çıkış noktasıyla doğrudan ilgili olan sorulara verilen yanıtların soru bazında yapılan analizlerinin sonuçları da çocukların olumlu gelişme gösterdiklerine işaret etmektedir. $\mathrm{Bu}$ da yaratıcı okuma uygulamalarının esasını oluşturan doğaçlama, dramatizasyon ve yaratıcı düşünme çalışmalarının çocukların okumaya karşı olan tutumlarının geliştirilmesinde etkili olduğunun bir göstergesi olarak kabul edilebilir. Sekiz haftalık yaratıcı okuma programının, uygulama saatleri dışında serbest etkinliklerle de (sokak tiyatrosu şenlikleri ve yerel edebiyat günleri) desteklenmesinin, çocukların okuma sürecine yönelik ilgilerinin ve heyecanlarının oluşmasına/artmasına katkıda bulunmuş olabileceği de söylenebilir.

\section{Sonuç ve Tartışma}

Çocukları yazınsal metinleri okumaya yönlendirmek ve heveslendirmek, onların okuma kültürü kazanmalarına yönelik adımlar atmalarına yardımcı olmak uzun soluklu çalışmalar gerektirmektedir. Okuma güçlügü çeken ya da kendi başına kitap okumaktan sıkılan çocuklar söz konusu olduğunda ise bu süre şüphesiz daha da uzamaktadır. Bilindiği gibi, kitapla tanışan çocuğun sadece okuma becerileri değil, iletişim becerileri de gelişir. Kitabın nasıl tutulacağı, sayfaların nasıl çevrileceği, resimlerin nasıl okunacağı gibi becerilerin de kazanılmasına katkıda bulunan kitaplarla tanışıklık süreci sanat çalışmalarıyla desteklendiğinde başka kazanımlara da kapı aralar. Okuma isteksizi çocuklara ulaşabilmek ve çocukların okuma sürecine yönelik tutumlarında olumlu değişmelere katkıda bulunabilmek okuma kültürü kazandırma çalışmalarının öncelikli hedeflerinden biri olmalıdır. Çünkü ulusal ve uluslararası başarı değerlendirme araştırmaları eğitim sistemimizin eksikliklerine dikkat çekerek özellikle okuma kültürü kazandırma yolculuğunda yeni yaklaşımların gerekliliğini açıkca göstermektedir.

Pek çok araştırmacı bu gereklilikten yola çıkarak çalışmalar yapmakta, çocukları kitaplarla buluşturmanın yollarını aramaktadır. Beers (Akt. Ariail ve Albright, 2006) işe okuma isteksizi çocukları tanımlamakla başlar. Ona göre, okuma isteksizleri "uyuşuk", "kopuk" ve "gönülsüz" olarak sınıflandırılabilir. Uyuşuk Okuma İsteksizlerini okumayı sevdikleri halde okumaya fazla 
zaman ayırmayanlar; Kopuk Okuma Isteksizlerini okumayı sevmeyen ama ileride okuyabileceklerini söyleyenler; Gönülsüz Okuma İsteksizlerini ise okumayı sevmeyen ve okumayacağını söyleyenler olarak tanımlar. Gerek Beers, gerekse okumaktan pek hoşlanmayan çocuklar üzerine çalışmalar yapan pek çok araştırmacı (Burger ve Winner, 2000; Cornett, 2006; Bidwell, 1990) bu çocukların "sesli okuma", "öykü anlatma", "yaratıcı drama" vb farklı uygulamalarla buluştuklarında, zamanla okuma hızlarının arttığını, okuma güdülerinin uyarıldığını ve kitap okumaya karşı geliştirdikleri olumsuz tutumlarını olumlu tutumlara dönüştürdüklerini söylemektedir. $\mathrm{Bu}$ tür gelişmeleri ortaya çıkaran araştırmaların sonuçlarından ve sanat çalışmalarıyla desteklenen ders programlarında öğrencilerin akademik başarılarının yükselişinden söz eden deneysel uygulamaların yöntemlerinden yola çıkılarak, bugün pek çok öğrenim alanına yönelik sanat destekli öğretim programları yapılandırılmakta ve uygulanmaktadır.

Podlozny (2000:239), yaklaşık 35 yıldır, drama ve akademik başarı arasındaki ilişkiyi araştıran hemen hemen 200 deneysel çalışmanın yapıldığını ve bu çalışmaların \% 40'nın drama ve sözlü/yazılı iletişim alanlarındaki başarıyı incelediğini söyleyerek dramanın eğitim alanındaki önemine dikkat çeker. Özellikle, okuma ve drama etkileşiminin, çocuğa pek çok şey kazandırdığ düşünülür. İkisinin de benzerliklerine dikkat çeken McInnes'e (Akt: Booth, 1985:193) göre, bu birliktelik, çocuğun yazılı olanla tecrübe, düşle gerçeklik ve kendiyle diğeri arasındaki bağı kurmasına yardım etmekte ve bu etkileşim etkin bir öğrenme ortamı yaratmaktadır.

Burger ve Winner (2000) de sanat çalışmalarıyla ve sanat projeleriyle desteklenen okuma sürecinin çocukların motivasyonunu artırdığını ve onları daha çok okumaya yönlendirdiğini söyleyerek McInnes'i destekler. Cornett'in (2006) araştırmaları da sanat merkezli okuma uygulamalarının okumayı öğrenme ve öğretme süreçlerine olumlu etkisi olduğunu vurgulayan ve görsel sanatların, dramanın, ritmin, dansın okuma başarısını artırdığına dikkat çeken çalışmalar arasında sayılabilir.

Okuma hızının gelişmesi için aynı metni birkaç kez okutacak uygulamaların gerekliliğinden bahseden Bidwell'i (1990) destekleyen Wolf (Akt. McMaster, 1998, s. 577) da drama çalışmalarının bu tekrarların yapılmasını olanaklı kıldığını vurgulayarak drama ve okuma süreçlerinin uyumlu birlikteliğinden söz eder. Dramatizasyon, role girme, öykünün farklı bölümlerini grup çalışmaları ile yeniden yorumlama vb çalışmaların yapılabileceğini belirten Wolf; çocukların metni sıkılmadan tekrar tekrar okuyabilmesi için okuma tiyatrosu provalarının etkili bir yöntem olduğunu söyleyen Bidwell (1990); drama teknikleri ile öykü içine yolculuk yapmanın çocukların öyküyü zihinlerinde yapılandırmalarına ve öykü haritası oluşturmalarına yardım ettiğini söyleyen Booth (1985); öykü haritasını kavrayan çocukların basit öykülerden karmaşık öykülere daha kolaylıkla geçtiklerini, farklı yazın türlerini ayırtedebildikleri ve eleştirel dinleyici olarak 
yaşıtlarının anlattıkları öykülerdeki zayıf ve güçlü noktaları farkedebildiklerini söyleyen Peck (1989) ve öykü anlatma tekniklerini kullanarak öykü okuma vb uygulamalarla yazınsal metinleri okumaya heveslendirici bir tutum kazandırılabileceğini söyleyen pek çok araştırmacı (Morrow, 1992; Neuman, 1999; Peck 1989; Rosenhouse, Feitelson, Kita ve Goldstein, 1997), dramanın ve diğer görsel sanatların okuma-anlama sürecine olan katkılarına dikkat çekerler.

Sonuç olarak, Okuyorum Oynuyorum isimli okuma programı, yukarıda söz edilen düşüncelerden, eğitim sistemimizdeki eksikliklerden ve Türkçe/Edebiyat öğretim programlarındaki gereksinimlerden yola çıkılarak yapılandırılmış bir yaratıcı okuma programıdır. Araştırmanın sonuçları, sekiz hafta (12 saat) süren yaratıcı okuma uygulamaları sonucunda çocukların okuma tutumlarının olumlu yönde değişmeye başladığını göstermektedir. Bir başka deyişle, yaratıcı okuma uygulamaları sonrasında çocuklar kitaplardan ve okuma-anlama etkinliklerinden daha fazla hoşlanma eğilimi göstermişler, okuma süreci ile ilgili kaygıları azalmış ve okuma-anlama konusunda kendilerini daha yeterli hissetmeye başlamışlardır.

Çok yönlü düşünmeyi öğretmek, düş gücünü geliştirmek elbette çok daha uzun soluklu çalışmalar gerektirmektedir. Ancak, yaratıcı okuma çalışmalarının, gerek Türkçe/Edebiyat öğretim programlarındaki geleneksel yaklaşımı değiştirme, gerekse eğitim anlayışındaki eksiklikleri giderme yolundaki önemli adımlardan biri olduğu söylenebilir.

\section{Kaynaklar}

Ariail, M. \& L K. Albright (2006). A Survey of Teacher's Read-Aloud Practices in Middle Schools. Reading Research and Instruction. 45 (2). 69-89

Bidwell, S. M (1990). Ideas for Using Drama to Enhance Reading Instruction. The Reading Teacher. 45. 653-654

Booth, D. (1985). Imaginary Gardens with Real Toads: Reading and Drama in Education. Theory into Practice. 24 (3). 193-198

Burger, K. \& E. Winner (2000). Instruction in Visual Art: Can It Help Children Learn to Read? Journal of Aesthetic Education. 34 (3/4). Special Issue: The Arts and Academic Achievement: What the Evidence Shows. 277-293

Cornett, C. E. (2006). Center Stage: Arts-based Read-alouds. The Reading Teacher. 60 (3)

Demirel, Ö. (2004). Türkçe Öğretimi. Ankara, PegemA Yayıncılı.

Isbell, R., Sobol J., Lindauer, L. \& Lowrance A. (2004). The Effects of Storytelling and Story Reading on the Oral Language Complexity and Story Comprehension of Young Children. Early Childhood Education Journal. 32 (3). 157-163 
McMaster, J. C. (1998). "Doing” Literature: Using Drama to Build Literacy. The Reading Teacher. 51 (7). $574-584$

Morrow, L. M. (1992). The Impact of Literature-Based Program on Literacy Achievement, and Attitudes of Children from Minority Backgrounds. Reading Research Quartely. 27 (3). 250-275

Neuman, S. B. (1999). Books Make a Difference: A Study of Access to Literacy. Reading Research Quarterly. 34 (3). 286-311

Palmer, B. \& Harshbarger, S. J. \& Koch, C. A. (2001). Storytelling as a Constructive Model for Developing Language and Literacy. Journal of Poetry Therapy. 14 (4). 199-212

Peck, J. (1989). Using Storytelling to Promote Language and Literacy Develeopment. The Reading Teacher. 43 (2). 138-141

PIRLS Raporu. MEB [online] http://www.meb.gov.tr

Podlozny, A. (2000). Strengthening Verbal Skills through the Use of Classroom Drama. Journal of Aesthetic Education. 34 (3/4). Special Issue: The Arts and Academic Achievement: What the Evidence Shows. 239-275

Rosenhouse, J., Feitelson, D., Kita, B. \& Goldstein, Z. (1997). Interactive Reading Aloud to Israeli First Graders: Its Contribution to Literacy Development. Reading Research Quartely. 32 (2). 168-183 


\title{
Summary
}

\section{Creatıve Drama Based Readıng Programme}

\author{
Nilay Yılmaz * \\ İstanbul Bilgi Üniversitesi
}

\section{Introduction}

Creative drama can be an effective way to develop a child's reading proficiency, and it can used to as a supplementary tool for motivating children to read and for reinforcing reading skills in a way that makes reading fun (Ross and Roe, 1982). When traditional reading methods fail, creative drama can also be used as an alternative approach to reading instruction.

Many of the studies dealing with creative dramatics have included consideration of students' attitudes toward the activities and their appreciation and enjoyment of literature. As it is known that creative drama can be a terrific motivational force for reading process because it encourages children to read the story again in order to visualize the setting and characters, get the sequence in mind for dramatization. Children can also be fascinated with this new creative reading experience which will seek them to read more along the lines, respond spontaneously and objectively.

As O’Shea and Egan (1982) emphasize, simulated experiences enliven ponderous reading material and bring it into perspective that children can understand. As they mention, dramatic action also stimulates and fosters their desire to share poetry, mythology, short stories, novels and plays that have been transformed into experimental situations which answers the questions: Who am I?, What are my roots? Where am I going? What will I become?

As it is mentioned before, creative experiences can be used for many different purposes in reading programme. This study was conducted to find out the effect of creative drama based reading programme on the development of reading attitudes.

\section{Method}

\section{Sample}

İstanbul Bilgi Üniversitesi, Fen Edebiyat Fakültesi, Türk Dili Birimi Öğretim Görevlisi 
The sampling of the study consisted of 258 children between the ages 9-13 attending to the reading programme called Okuyorum Oynuyorum (I'm Reading and Playing) at TEGV (The Organization of Volunteers of Education).

\section{Data Collection Instrument}

"The Questionnaire Form of the Reading Attitudes" was used to collect data. It was developed by the researcher and a field expert at TEGV. The reliability coefficient was found as .79 by using Cronbach Alpha realibility coefficient. The questionnaire form consisted of four parts which are 'creative reading', 'liking', 'anxiety' and 'proficiency', including 30 items in total. Children responded the questions in the form by indicating 4 level styles "Strongly Agree", "Agree", "Disagree" and "Strongly Disagree". The scoring was sorted out starting from "Strongly Disagree" varying from 1 to 4 . The highest score a child gets in the form is 120 while the lowest one is 30 .

\section{Procedure}

"The Questionnaire Form of the Reading Attitudes" was applied to the children at the very beginning of the programme as a pre-test and at the end of programme as a post-test. For a duration of 8 weeks (12 hours), 8 reading materials in total (one for each week) including short stories, poems and pictures supported by creative tasks were applied. In the warm-up stages of each session children were expected to play the games which were related to the theme of the story. Then came storytelling, comprehension tasks expanded by creative works like drawing, creative writing etc. and drama techniques like improvisation, conscience alley, group sculpture, inner voice, interviews, letters, narration, private property, still photographs etc. Children were expected to express their thoughts and feelings using a variety of creative tasks.

\section{Conclusion and Suggestions}

To purpose of this study was to create positive attitudes, thoughts and emotions for children's books and to arouse curiosity towards reading process in children. Among creative tasks the creative drama played a significant role in developing the positive attitudes towards reading. Depending on the results of study, children who took drama-based creative reading programme liked the reading process; their anxiety levels about reading were decreased and they felt proficient in reading comprehension.

In conclusion, drama based reading programme is an invaluable tool for educators to help building the culture of reading for children because it supports every aspect of literacy development. And implementing a creative reading programme can be a good approach to promote 
children's interest in literacy because creative comprehension tasks encourage the affective aspects of reading in a valuable social context.

Depending on these results, the followings can be recommended:

Implementing a creative reading programme at schools can be an important aspect of the curriculum.

Libraries can hold creative reading sessions in libraries regularly to help create positive attitudes for children's books and arouse curiosity towards reading process in children.

Teachers and librarieans can be led to such activites, seminars, workshops, courses etc. on the importance and usage of creative drama in reading process.

Longitidunal studies should be conducted to find out the relationship of creative dramatics and reading process. 